\title{
A Factual Analysis of Teacher Working Group (Twg) Physical Education Health and Sport in North Indralaya South Sumatera, Indonesia
}

\author{
Syamsuddin $^{1}$, Tandiyo Rahayu ${ }^{2}$, Setya Rahayu ${ }^{3}$, Totok Sumaryanto ${ }^{4}$ \\ ${ }^{1}$ Educational Quality Assurance Council of South Sumatra, Indonesia \\ ${ }^{2,3,4}$ Graduate School, Sports Education Study Program, Universitas Negeri Semarang, Indonesia \\ ${ }^{1}$ Coresponding email: syamsuddinkarigamas@ gmail.com
}

\begin{abstract}
The professionalism of the Physical Education Health And Sport (PEHS) teachers is determined by their competence. The means of competence development can be done through Teachers Working Group (TWG) PEHS. The factual conditions in the implementation of TWG PEHS has not matched with existing guidelines. The purpose of this study is to analyse factual implementation of TWG PEHS in North Indralaya District, Ogan Ilir Regency. The data were obtained by observation method, interviews, questionnaires, documentation studies, literature studies. The entire data obtained were reduced to get the data that were really important, then it were analysed by using Strength, Weaknesses, Opportunities, Threats (SWOT) analysis. The result of SWOT analysis is more deeply analysed in the Focus Discussion Group (FGD) and it was analysed to get the final conclusions. The conclusions are the PEHS TWG is formed on the basis of mutual interests and needs between the Regional Technical Implementation Unit (RTIU) of the Board of Education and Culture of North Indralaya District along with PEHS teachers, the Principals Working Deliberation (PWD), as well as the Ogan Ilir district government. The significance of this study is as input for RTIU Board of Education and Culture in fostering TWG PEHS.
\end{abstract}

Keywords: SWOT, FGD, TWG PEHS.

\section{Introduction}

Teacher working group (TWG) is a structural professional teacher organization established by the teachers of a region or groups of schools. As a means to exchange experiences to improve teachers' ability and improve the quality of learning according to the Hati, (2017). Researchers examined several teachers from several schools. The activities of TWG PEHS in North Indralaya District, Ogan Ilir Regency in 2016-2017 are attended by 19 of Elementary Schools and 2 of Madrasah Ibtidaiyah (Islamic Elementary School) both public and private schools, a total of 21 schools, with 27 PEHS teachers. Based on the data, there are 3 schools that have not joined the TWG PEHS due to the geography condition of the school and there is no PEHS teacher there.

The problems appear in some meetings in TWG PEHS of North Indralaya District, the participants reduced by the time. The participation between the first and next meetings varied, so it is difficult to explain the significance of this TWG PEHS. It is make worse by bureaucracy from schools, administrators, resource persons, educational background of PEHS teachers, guidance on the implementation of TWG especially PEHS, school distance, and less attractive of work program.

Based on the problems above, it can be identified the first problem of the development of learning methods of PEHS is on the SchoolBased Curriculum 2013 (KTSP.13), it demands professionalism of PEHS teachers, to adapt, where the element of attitude becomes important as a perfecting from the end of the learning process of PEHS. Second, the mindsets of PEHS teachers should be more open to any changes that occur, they are demanded to be creative and active to develop themselves, one of them through the means of organization called TWG PEHS.

If the activities of the TWG are felt necessary, then there will be an organizational culture. Organizational culture means to whom and what organization is directed, Anwar (2013). Organizational culture implies the existence of creativity and high performance of the actors. Performance and creativity of teachers positively affect the productivity of TWG, Heri (2012). These two arguments support the importance of cooperation and organizational goals.

The implementation of TWG PEHS activities must be in accordance with the standard operating procedures for the implementation of TWG, therefore, it will be 
affecting the improvement of professionalism of its members. Many problems in implementing TWG PEHS should get serious attention from relevant institution in order to obtain effective and efficient solutions. Therefore, this study is important to be conducted. The purpose of this study is to find a theoretical study regarding the implementation of TWG PEHS in North Indralaya District, Ogan Ilir Regency. Its significance of the study as policy recommendation for the Regional Technical Implementation Unit (RTIU) of District level and Ogan Ilir Regency.

\section{Methods}

The research was initially began with field observation about the implementation of TWG PEHS, then conducted literature study, interviews, open questionnaire and documentation study and triangulate them. Then, the data were analysed by using SWOT (Strength, Weakness, Opportunity, and Threat). The purpose of SWOT analysis is to know the strengths and weaknesses (Rangkuti, 2002).

Based on SWOT analysis, it was obtained 4 analysis of problem-solving strategy. Furthermore, the four strategies were deeply analysed through a forum of experts in Focus Group Discussions (FGD) activities. FGD is a process of collecting data and systematic information about a particular problem that is very specific through group discussion, Irwanto (2006). FGD contained three keywords: a. discussion, b. group, c. focused. The results of this FGD became the final findings of this research, it was in the form of recommendations.

The implementation of research in TWG PEHS of North Indralaya District, Ogan Ilir District. There are 27 teachers as object of the study. The research design adopted discrepancy model that emphasizes the view to seek or trace the gap point of the implementation of a program, Sulastri (2012).

According to the guidelines for the development of TWG activities, there are 7 components: 1) organization, 2) programming, 3) human resources, 4) facilities and infrastructure, 5) management, 6) financing, and 7) monitoring and evaluation, Department of National Education (2009).

\section{Results and Discussion}

Reviewing from an organizational perspective, the implementation of TWG PEHS of North Indralaya District, Ogan Ilir Regency is still not optimal. Its Implementation is not running well, it tends to follow the situation and conditions in the District or Regency. Completeness of an organization's administration has not completed yet, for more details. it can be seen in the table 1 .

Table 1. Factual Condition of TWG PEHS in North Indralaya District

\begin{tabular}{|c|c|c|c|}
\hline No & Item & Condition & Notes \\
\hline 1 & $\begin{array}{l}\text { Decree of } \\
\text { TWG PEHS }\end{array}$ & $\begin{array}{l}\text { Available on } \\
\text { July } 18, \\
2017\end{array}$ & $\begin{array}{l}\text { There is no } \\
\text { duty period }\end{array}$ \\
\hline 2 & $\begin{array}{l}\text { Organizationa } \\
1 \text { structure }\end{array}$ & Available & $\begin{array}{l}\text { Does not } \\
\text { match the } \\
\text { instructions }\end{array}$ \\
\hline 3 & $\begin{array}{l}\text { Articles of } \\
\text { association }\end{array}$ & Unavailable & $\begin{array}{l}\text { Have not } \\
\text { made it yet }\end{array}$ \\
\hline 4 & $\begin{array}{l}\text { Annual } \\
\text { Program }\end{array}$ & Available & $\begin{array}{l}\text { The format } \\
\text { does not } \\
\text { match the } \\
\text { instructions }\end{array}$ \\
\hline 5 & $\begin{array}{l}\text { Semester } \\
\text { Program }\end{array}$ & Available & $\begin{array}{l}\text { The format } \\
\text { does not } \\
\text { match the } \\
\text { instructions }\end{array}$ \\
\hline 6 & $\begin{array}{l}\text { Curriculum } \\
\text { Vitae of TWG } \\
\text { PEHS } \\
\text { members }\end{array}$ & Available & $\begin{array}{l}\text { Less } \\
\text { complete }\end{array}$ \\
\hline 7 & $\begin{array}{l}\text { Minutes of } \\
\text { Establishment } \\
\text { of TWG } \\
\text { PEHS }\end{array}$ & Unavailable & \\
\hline 8 & $\begin{array}{l}\text { Activity } \\
\text { Documentatio } \\
\mathrm{n} \text { of the last } 2 \\
\text { years }\end{array}$ & Available & Incomplete \\
\hline 9 & Secretarial & Available & $\begin{array}{l}\text { At } \\
\text { principal's } \\
\text { school of } \\
\text { TWG PEHS }\end{array}$ \\
\hline 10 & $\begin{array}{l}\text { Financial } \\
\text { administration }\end{array}$ & Available & $\begin{array}{l}\text { Not } \\
\text { complete }\end{array}$ \\
\hline
\end{tabular}

At District level, there should be a special team as a district-level development team, but, unfortunately, it also does not available. According to the regulation, at the Regency/ Municipality level, there should be a special team whose members consist of; Regency/ Municipality Education Board, Lecturers (Teacher Training Institute/Higher Education), 
Instructors, School Supervisors, Selected School Principals, Selected Teachers, Structural Officials, and relevant instructors according to their fields.

The decree of the organization of TWG PEHS is structured as follows; Chairman, Secretary, Treasurer, management section and members. The selection of the management should be through a democratic election process and authorized by the RTIU valid for 4 (four) years of service, thus the objectives and significances of the organization can be achieved. The same thing was stated by Akbar et al (2017). An organization is a reflection of the awareness and maturity of human thinking that the importance of structured in the process of achieving goals.

The arrangement of the TWG program is basically the main activity in the implementation of TWG activities, which play a role in improving the competence and professionalism of teachers. TWG is a means for teachers who join organizations, organization groups which aimed at making teachers more professional in improving the quality of education in basic organizations through a professional supervision system and active teaching and learning, Purnama (2013). TWG is a workshop in planning, implementing and evaluating teaching and learning activities.

From the observation in North Indralaya TWG PEHS, it is obtained information that in the preparation of the program, it tends to be top down and monotonous. The members feel bored, so it affects the participants to take apart. According to the guidelines for the implementation of TWG before determining the program and activities, the steps are as follows: 1) Analysis of teacher competence needs include professional competence, pedagogical, personality and social, 2) The result of analysis is written in the form of semester and annual schedule, 3) the arrangement of general programs, core programs and support, 4) The program of needs analysis is set in a schedule of at least 12 meetings a year, 5) The intended programs and activities are arranged by a special team/board and it is communicated to group members.

Human resources of TWG members in North Indralaya are 27 people and they are from various education level starting from Senior High School level 18,5\%, Diploma $7,4 \%$, Strata $1 / 2$ (74.0\%). Reviewing from the status of PEHS teachers who already work as civil servants (40.7\%) and honorary (59.3\%) with teaching experience between 2-28 years. TWG PEHS activities have been followed by them since 2002, 2006, 2007, 2008, 2016, based on age $\geq 40$ years $29.6 \%,<40$ years $70.4 \%$. There are sport inspectors but they are assigned as an overseas school supervisor.

The background of 27 people of their education is very diverse, ranging from alumni School of Sports Teacher (SST), Diploma II of Open University, Class program of religion /class teachers who become sports teachers, for Bachelor if it is reviewed further, teachers come from 3 universities, they are alumni of Faculty of Teacher Training Education (FTTE) Physical Education and Health Sciences Study Program Sriwijaya University (UNSRI), alumni of FTTE of sport education study program of PGRI University Palembang and alumni of FTTE Physical Education and Health Sciences Study Program Bina Dharma Palembang and 1 person of graduate of sport program of UNSRI.

The development of human resources, especially educators, in this case the professional development of teachers, is an effort to prepare teachers to have various insights, knowledge, and skills and give confidence to carry out their duties and obligations as professional teachers and educators. Indication of teacher performance improvement in learning can be realized through empowerment potential and teacher achievement, one of them is through TWG, Wartoni (2013). According to the TWG guidelines, human resources (HRD) that is needed to support the implementation of the TWG consists of members, instructors, tutors, school supervisors, widyaiswara (trainer), lecturers and structural officials and nonstructural officials at RTUI of Regency/District education board. With diverse educational backgrounds and work experience, it greatly affects organizational activities.

Facilities and infrastructure is an important part in the implementation of TWG activities, there are main and supporting. According to Hadi (2013), everything outside the arena that support sports activities, it is called as sports infrastructure. Facilities and infrastructure of TWG PEHS in North Indralaya are not optimal and has not fulfilled minimal needs, especially for the core school. The main Facilities and infrastructure that 
should be provided in the core school are computer, OHP/LCD projector, telephone/ facsimile. Supporting Facilities and infrastructure of TWG are laboratory, library, internet network and so forth.

In fact, in the aspect of these facilities and infrastructure, they still borrow at the host schools when they held the meeting. Even, they sometimes borrow from other schools, such as, the nearest Junior High School. Another problem is the voltage that has not been optimal so that many school electronic devices are damaged.

The management of TWG PEHS of North Indralaya program is scheduled for 1 year program. In the first semester, the activities are 1) Opening and preparation of TWG program, 2) Planning of sports activities of Celebration of Independence Day of The Republic of Indonesian, 3) Making learning Media in the first semester, 4) Making the next learning Media, 5) Activities plan of District Gymnastics of Physical Health, and 6) Olympic National Sports School activity plan in District level. In the second semester, the activities are: 1) Establishment of Olympic National Sports School committees, 2) Implementation of matches and competitions, 3) Training of elected athlete, 4) The continuation of athlete training, 5) regency level match, and 6) Evaluation results of all activities.

The standard operational guidelines for the implementation of the TWG states that a general program, core program (regular program and development program) and supporting programs should be developed. The program should be detailed in the form of activities in each meeting, at least 12 activities during the year. Based on the above findings, TWG PEHS should need to select priority programs and activities, and each of these activities has a person in charge that will be responsible in accordance with the terms of reference that are planned and coordinated with the Ogan Ilir Regency Development Team as well as with the relevant parties.

Financing is also an important aspect of an organization. Currently, the TWG that has formed, its funds source is usually obtained from self-help schools. This happens because there are few TWG members who understand about funding or budget assistance from the government. According to the statement of the head of TWG in North Indralaya, they have received the second help of block grant, in the previous management period. Some sources of funds that can be utilized are as follows; membership fees, Indonesia's School Grants Program (BOS), State Budget (APBN), Provincial Budget (APBD), School Committee/Education Board, Regional Technical Implementation Unit in the District level, Educational Quality Assurance Council and others.

The monitoring and evaluation process is important in ensuring the accountability of the TWG PEHS program. Monitoring involves the implementation of programs and activities, and evaluations are carried out afterward. Observation results of TWG PEHS in North Indralaya District, Ogan Ilir Regency, the fact in the field shows that the monitoring and evaluation aspects have not been well implemented, it can also be seen from the not orderly in the preparation of activity reports and financial statement administration.

Results of discussion to the seven aspects further data are reduced, and the data are obtained from internal and external factors. The data of internal and external factors are then analysed by using SWOT. The SWOT analysis yields four alternative strategies as follows table 2 .

The results of this study are useful for the organizers of TWG PEHS to become independent TWG PEHS, RTIU in the District level, education authorities of Ogan Ilir regency and other related parties in developing teacher empowerment strategy through TWG PEHS according to procedure. Other researchers as materials reference.

$\begin{array}{lll}\text { Notes: } & \\ \text { PWD } & : \text { Principals Working Deliberation } \\ \text { EQAC } & : \text { Educational Quality } \\ & \text { Assurance Council } \\ \text { UNSRI } \quad: \begin{array}{l}\text { Sriwijaya University/ Universitas } \\ \text { Sriwijaya }\end{array} & \\ \text { RTIU } \quad: \begin{array}{l}\text { Regional Technical } \\ \text { Implementation Unit }\end{array}\end{array}$

Notes:

PWD : Principals Working Deliberation

Assurance Council

Sriwijaya University/ Universitas

Implementation Unit 
Table 2. SWOT Matrix of Internal and External Factors

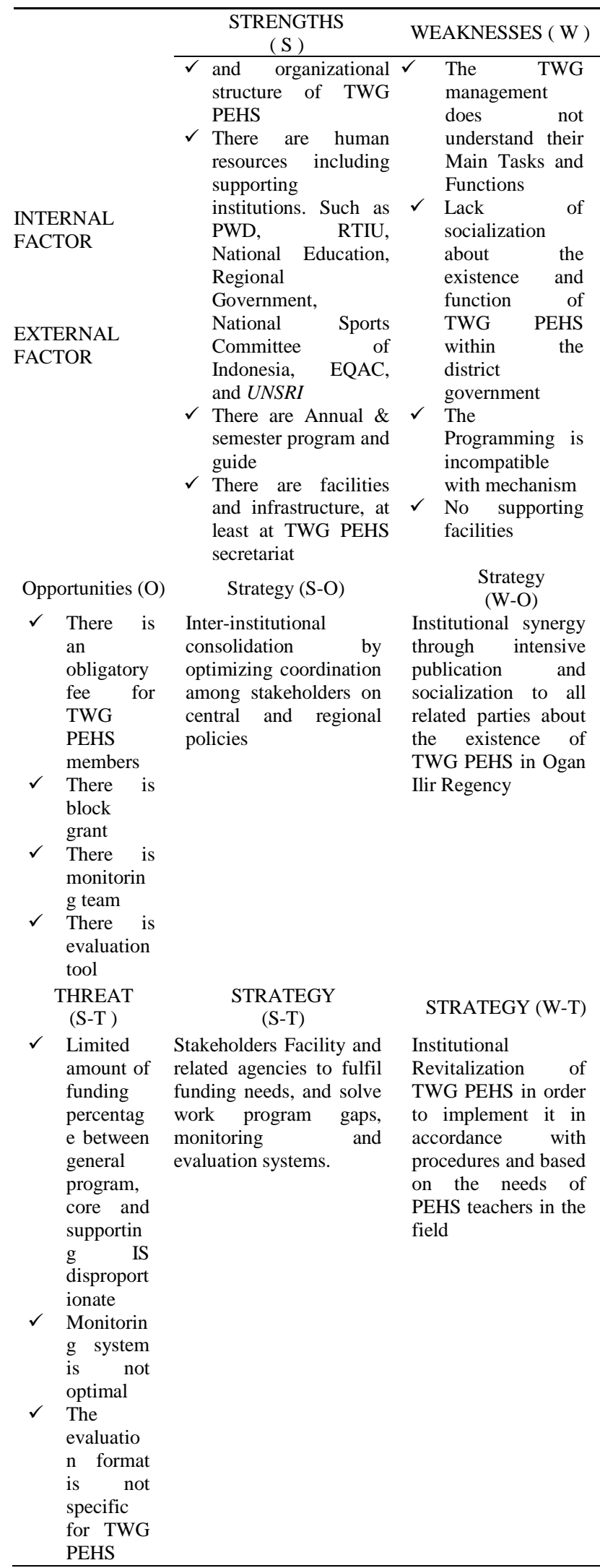

\section{Conclusion}

The implementation of TWG PEHS in North Indralaya District Ogan Ilir Regency has not run well in accordance with the standard operating procedure of TWG/ TECP implementation. There are four strategies that must be applied in empowering teacher of TWG PEHS in Ogan Ilir Regency that is 1) inter-institutional consolidation, 2) institutional synergy, 3) stakeholder facility 4) Institutional revitalization of TWG PEHS. TECP = Teacher Education Consensus Points/MGMP

\section{References}

Akbar, R A \& Rukanto, 2017.Pengaruh Implementasi Visi dan Budaya Organisasi dalam Pendidikan. Jurnal Manajemen, Kepemimpinan, dan Supervisi Pendidikan. 2(1):127-142. PPS Universitas PGRI. Palembang

Anwar, M I. 2013.Administrasi Pendidikan dan Manajemen Biaya Pendidikan. Jakarta: Raja Grafindo Persada.

Depdiknas,2009.Prosedur Opersional standar penyelengaraan KKG MGMP.Depdiknas. Jakarta.

Hadi, S. 2013. Survei Pendidikan Jasmani, Olahraga, Dan Kesehatan Pada Satuan Pendidikan SD, SMP, SMA Negeri Se-KecamatanKarangan Kabupaten Trenggalek. Jurnal Pendidikan Olahraga. 3 (1): 51-56. Surabaya.

Hati, J. 2017. Upaya Meningkatkan Kompetensi Guru dalam Penyusunan RPP melalui pendampingan berbasis KKG Bagi Guru SD 46 Cakranegara Semester Dua. JIME, 3(1): 131-14. ISSN 2442-9511.NTB.

Irwanto, 2006.Focused Group Discussion (FGD). Sebuah Pengantar Praktis. Jakarta. Yayasan Obor Indonesia.

Purnama, H. 2013. Pengaruh Kinerja dan Kreativitas Guru Terhadap Produktivitas Kelompok Kerja Guru. Jurnal Ilmiah Mahasiswa Pascasarjana Administrasi Pendidikan, 1 (1): 51-56. Universitas Galuh. Jawa Barat.

Rangkuti, F.(2002). Analisis SWOT Teknik Membedah Kasus Bisnis. PT. Gramedia Pustaka Utama, Jakarta.

Sulastri, 2012.Analisis Kesenjangan (Discrepancy) Pelaksanaan Standar 
Proses pada Pembelajaran Tematik di Kelas Permulaan Sekolah Dasar seKecamatan Kuta, Kabuapten Bandung Provinsi Bali tahun 20112012. Jurnal Penelitian Pascasarjana Undiksha. 2 (2): 3546. Bali
Wartoni, B. K. 2013. Evaluasi Keefektifan Kelompok Kerja Guru (KKG) pada Program Bermutu di Kabupaten Batang Jawa Tengah. Jurnal Evaluasi Pendidikan. 1(1): 93-101. PPS UNY. Yogyakarta. 